\title{
Comparison of Phadebact coagglutination tests with counterimmunoelectrophoresis for the detection of bacterial antigens in cerebrospinal fluid
}

\author{
DS TOMPKINS
}

From the Department of Microbiology, School of Medicine, University of Leeds, Leeds LS2 9JT

SUMMARY One hundred and seventeen specimens of cerebrospinal fluid from 94 patients were examined for the presence of pneumococcal and Haemophilus infuenzae type b antigens using counterimmunoelectrophoresis and coagglutination tests. The coagglutination method using Phadebact reagents was as sensitive as counterimmunoelectrophoresis, but culture was a more sensitive diagnostic procedure than either test. A meningococcus coagglutination reagent, included in a prototype meningitis diagnostic kit, was also found to be as sensitive as counterimmunoelectrophoresis when tested on culture-positive cerebrospinal fluid specimens. Coagglutination tests for the detection of bacterial antigen are useful supportive tests when used in conjunction with direct microscopy and culture for bacterial pathogens.

Several techniques have been described which increase the speed and sensitivity of the diagnosis of bacterial meningitis in comparison with a Gramstained film and culture of cerebrospinal fluid (CSF). There are non-specific indicators of bacterial infection such as the detection of Gram-negative endotoxin and the measurement of lactate in CSF, ${ }^{12}$ and the measurement of $\mathrm{C}$-reactive protein in serum. ${ }^{3}$ Specific techniques include the detection of bacterial antigen in CSF by counterimmunoelectrophoresis (CIE). Early studies suggested that the sensitivity of CIE was comparable to that of Gram stain and culture of CSF combined, ${ }^{5}$ but this has not been confirmed subsequently. ${ }^{6-9}$ Many variations in technique have been described. ${ }^{10}$

Slide agglutination techniques are as sensitive and specific as CIE for the detection of bacterial antigens in CSF. ${ }^{68}$ Coagglutination (COA) reagents are suspensions of staphylococci treated to expose superficial protein A coated with specific antisera. Commercially prepared reagents are available as the Phadebact Pneumococcus Test and Phadebact Haemophilus Test (Pharmacia Diagnostics) for the identification of Streptococcus pneumoniae and capsulated Haemophilus infuenzae. The purpose of this study was to compare these two kits with CIE for the detection of bacterial antigen in CSF. At the end of

Accepted for publication 23 February 1983 the study a prototype meningitis kit incorporating a meningococcus reagent was also compared with CIE on culture-positive CSF specimens.

\section{Material and methods}

CSF SPECIMENS

Cell count, Gram stain and bacterial culture on blood agar and heated blood agar in $5 \% \mathrm{CO}_{2}$ were performed on all specimens of CSF submitted to the diagnostic laboratory of the Department of Microbiology, University of Leeds. Further investigations for Myco tuberculosis, fungi, viruses, etc were carried out when appropriate. COA tests for Haemophilus inftuenzae and pneumococcus antigen were performed on all CSF specimens with a neutrophil polymorph count of greater than $10 \times 10^{6} / 1$, and on the supernatant of centrifuged, bloodstained CSF specimens with a ratio of white blood cells to red cells of greater than 1:500. Specimens were similarly cultured and tested by COA in the Bacteriology Laboratories of the Bradford Royal Infirmary, St Luke's Hospital, Bradford and Staincliffe General Hospital, Dewsbury; any remaining CSF was stored at $-20^{\circ} \mathrm{C}$ and later submitted to the Department of Microbiology, University of Leeds where $\mathrm{CIE}$ and repeat $\mathrm{COA}$ reactions were tested. A small number of specimens were submitted from other laboratories in West Yorkshire. 
COUNTERIMMUNOELECTROPHORESIS

CIE was performed on unheated CSF using Shandon-Vokam CIE equipment. Barbiturate buffer ( $\mathrm{pH} \mathrm{8.2,} \mathrm{ionic} \mathrm{strength} 0.05$ ) was used to prepare the $1 \%$ agarose gel and in the buffer tanks. ${ }^{4}$ A constant current of $2 \mathrm{~mA} / \mathrm{cm}$ width of gel was applied, as recommended for the equipment used. Slides were examined after $30 \mathrm{~min}$ and one hour for lines of precipitation, and then placed in a wet chamber at $4^{\circ} \mathrm{C}$ and re-examined after overnight cooling. Four antisera were used for CIE; Pneumococcus omniserum (Statens Seruminstitut, Copenhagen, Denmark), Haemophilus infuenzae type b (Difco), meningococcus polyvalent groups $\mathrm{ABCD}$, and meningococcus polyvalent groups $\mathrm{XYZ}$ and W135 (Wellcome). Three antigen controls were prepared from laboratory cultures of $N$ meningitidis (group A), Strep pneumoniae and Haemophilus infuenzae type $b$ and were included in each electrophoresis. ${ }^{11}$

\section{COAGGLUTINATION TESTS}

Initially COA reagents were supplied in a lyophilised form and were reconstituted with buffer and used in accordance with the manufacturer's instructions. Reagents are now supplied ready for use, as staphylococcal suspensions coated with rabbit antibody and stained with methylene blue. The Pneumococcus kit comprises two reagents; one is coated with anti-pneumococcal antibodies and the other with gamma globulin from non-immunised rabbits, as the control reagent. The Haemophilus kit

Table 1 CIE and COA reactions of 117 specimens of CSF

\begin{tabular}{llll}
\hline Bacteria isolated & $\begin{array}{l}\text { Number of } \\
\text { CFSs }\end{array}$ & $\begin{array}{l}\text { Positive by } \\
\text { CIE }\end{array}$ & $\begin{array}{l}\text { Positive by } \\
\text { COA }\end{array}$ \\
\hline Strep pneumoniae & 14 & 13 & 13 \\
H infuenzae & 10 & 8 & 8 \\
$N$ meningitidis & 13 & 6 & NT \\
Other species $\dagger$ & 9 & 0 & 0 \\
No bacterial growth & 71 & $4^{*}$ & $4^{*}$ \\
\hline
\end{tabular}

tSee Results.

* See Table 2.

NT $=$ not tested. also comprises two reagents, one coated with rabbit antibody to Haemophilus influenzae type b, and the other antibodies to Haemophilus infuenzae types a $c$ d e f.

Approximately one $\mathrm{ml}$ of CSF was heated for 10 min, in a test tube placed in a water bath at $80^{\circ} \mathrm{C}$, to eliminate non-specific agglutinations. Four separate drops of CSF were then placed on one of the white cards provided, and one drop of each reagent added. Each reagent and CSF were mixed and the card rocked slowly and observed for agglutination for two minutes. Reactions were graded visually ( + to $++++)^{6}$ Instructions provided with the latest reagents suggest that 30 seconds should be the limit for observation of reactions, but some of the weaker agglutinations were not observed until one to two minutes had elapsed.

MENINGITIS KIT

A prototype meningitis COA kit was available for evaluation at the end of the study. This comprised polyvalent pneumococcus reagent, Haemophilus inftuenzae (type b) and (types a, c-f) reagents and a new meningococcus reagent, all ready for use. The kit was tested on CSF specimens which had been stored at $-20^{\circ} \mathrm{C}$ using the method described above.

\section{Results}

One hundred and seventeen specimens of CSF from 94 patients were tested for pneumococcal, meningococcal and Haemophilus infuenzae type b antigens by CIE, and pneumococcal and Haemophilus infuenzae type $\mathrm{b}$ antigens by COA. Forty-six of these specimens, obtained at presentation, were positive on culture for bacteria, and antigen was detected as shown in Table 1 . One specimen was positive for pneumococcal antigen by CIE and negative by COA; one was positive by COA and negative by CIE. Two CSFs, from which Haemophilus infuenzae was cultured, contained no antigen detectable by CIE or COA when tested after storage

Table 2 Persistence of pneumococcal antigen in CSF detected by CIE and COA

\begin{tabular}{llllll}
\hline Patient & Days after initial specimen & Gram film & Bacterial culture & CIE & COA \\
\hline A & $0^{*}$ & + & + & + & + \\
A & 3 & + & - & + & + \\
A & 5 & - & - & + & + \\
A & 6 & - & + & + & + \\
B & 9 & + & + & + & + \\
B & 0 & + & + & + & + \\
C & $\mathbf{0}$ & + & + & + & + \\
C & 2 & + & + & + & + \\
D & 0 & + & - & + & + \\
D & 2 & - & & + & + \\
D & 4 & & & + & + \\
\hline
\end{tabular}

${ }^{*}$ Initial specimen taken on day of presentation. 
at $-20^{\circ} \mathrm{C}$, although COA had been positive on initial testing of one of these specimens. One culture of meningococcus consisted of one colony only; CIE was negative on this specimen. No cross-reactions were observed. The other bacteria cultured were Staph aureus $(\times 2)$, Klebsiella aerogenes $(\times 2)$, Mycobacterium tuberculosis ( $\times 2$ ), Staph epidermidis, E coli and Listeria monocytogenes.

Eight specimens of CSF were submitted to monitor the progress of four of the patients with pneumococcal meningitis (Table 2). The four specimens obtained at presentation of these patients were all positive on Gram-stain, culture, CIE and COA. Antigen was detected in one case after organisms could no longer be seen in Gram-stained films of the CSF, and in two cases after culture had become negative.

\section{COMPARISON OF THE SENSITIVITY OF CIE AND COA FOR ANTIGEN DETECTION}

Four CSF specimens, strongly positive by both CIE and $\mathrm{COA}$ on initial testing, and stored at $-20^{\circ} \mathrm{C}$, were tested. Doubling dilutions of each CSF were made in barbiturate buffer. Each dilution was tested for antigen by CIE, then heated and tested by COA as described above (Table 3 ). COA was as sensitive as CIE for the detection of bacterial antigen.

\section{MENINGITIS KIT}

Twenty-four specimens of CSF, all positive on bacterial culture and from different patients, were used to evaluate the prototype meningitis kit (Table 4). The specimens had been previously tested by CIE and stored at $-20^{\circ} \mathrm{C}$. Of the 11 specimens tested

Table 3 Comparison of the sensitivity of CIE and COA on CSF from four patients

\begin{tabular}{llcc}
\hline Patient & Bacterial isolate & Titre-CIE & Titre-COA \\
\hline A & pneumococcus & 128 & 128 \\
E & pneumococcus & 32 & 64 \\
F & H influenzae & 4 & 16 \\
G & H influenzae & 2 & 2 \\
\hline
\end{tabular}

from which meningococci were cultured, six were positive for antigen by both CIE and COA. One cross-reaction was observed; a specimen positive on culture for Haemophilus inftuenzae gave a positive reaction on CIE and COA for Haemophilus infuenzae type $\mathrm{b}$ antigen, but also gave a weak positive reaction with the meningococcal $\mathrm{COA}$ reagent. Unfortunately, no more of this CSF was available for study and the organism had been discarded.

\section{Discussion}

The most sensitive method available at present for the detection of bacteria in CSF is culture, and for rapid diagnosis a Gram-stained film is more sensitive than either CIE or slide agglutination tests. ${ }^{8}$ However, Gram-stained smears can be misleading and detection of antigen by rapid methods can lend valuable support to a presumptive diagnosis based on microscopy, so that specific antibiotic therapy can be initiated before culture results are available. Expensive equipment is required for CIE. Freshly prepared agarose-coated slides should be available if the test is to be used as an emergency procedure and electrophoresis may be required for a period of up to one hour. The technique is not suited to "oncall" work. No expensive equipment is required for $\mathrm{COA}$, the reagents are supplied ready for use, and the test is completed in $15 \mathrm{~min}$. Positive reactions were clearly defined in the COA test, whereas some lines of precipitation clearly visible after 30 minutes CIE became blurred at one hour and other lines were very faint even after one hour of electrophoresis. ${ }^{12}$ The results obtained with commercially available reagents confirm previous observations that COA is as sensitive, or more sensitive, than CIE for bacterial antigen detection in CSF. ${ }^{68}$

Antigen was detected only in CSF specimens positive on culture for bacteria, or from patients with previous CSF specimens positive on culture for bacteria. Prior treatment with antibiotics decreases the numbers of organisms present in the CSF, adversely affecting Gram stain, culture and the amount of

Table 4 Evaluation of Prototype Meningitis Kit

\begin{tabular}{|c|c|c|c|c|c|c|c|c|c|}
\hline \multirow{2}{*}{$\begin{array}{l}\text { Bacterial } \\
\text { culture }\end{array}$} & \multirow{2}{*}{$\begin{array}{l}\text { No of } \\
\text { CSFs }\end{array}$} & \multicolumn{4}{|c|}{ CIE positive } & \multicolumn{4}{|c|}{ COA positive } \\
\hline & & $\begin{array}{l}\text { pneumo- } \\
\text { coccus }\end{array}$ & $\begin{array}{l}H \text { infuenzae } \\
\text { type b }\end{array}$ & $\begin{array}{l}\text { meningo- } \\
\text { coccus } \\
\text { groups } \\
\text { ABCD }\end{array}$ & $\begin{array}{l}\text { meningo- } \\
\text { coccus } \\
\text { groups } \\
\text { XYZ W135 }\end{array}$ & $\begin{array}{l}\text { pneumo- } \\
\text { coccus }\end{array}$ & $\begin{array}{l}H \text { infuenzae } \\
\text { type b }\end{array}$ & $\begin{array}{l}H \text { infuenzae } \\
\text { types acdef }\end{array}$ & $\begin{array}{l}\text { meningo- } \\
\text { coccus }\end{array}$ \\
\hline $\begin{array}{c}\text { Streptococcus } \\
\text { pneumoniae } \\
\text { Haemophilus }\end{array}$ & 7 & 7 & 0 & 0 & 0 & 7 & 0 & 0 & 0 \\
\hline $\begin{array}{l}\text { infucenzae } \\
\text { Neisseria }\end{array}$ & 5 & 0 & 4 & 0 & $\mathbf{0}$ & 0 & 4 & 0 & 1 \\
\hline $\begin{array}{l}\text { meningitidis } \\
\text { Listeria }\end{array}$ & 11 & 0 & 0 & 6 & $\mathbf{0}$ & 0 & 0 & 0 & 6 \\
\hline monocytogenes & 1 & 0 & 0 & 0 & $\mathbf{0}$ & 0 & $\mathbf{0}$ & 0 & 0 \\
\hline
\end{tabular}


antigen available for detection..$^{13} \mathrm{~A}$ threshold concentration of bacteria is required for antigen detection by CIE and $\mathrm{COA}^{78}$ and this is higher than the threshold for detection of bacteria by direct microscopy. ${ }^{8}$

Although bacterial antigen in CSF is reported to be stable at $-20^{\circ} \mathrm{C}$ for up to six months ${ }^{69}$ one specimen of CSF initially positive by COA was negative by CIE and COA for Haemophilus infuen$z a e$ type $\mathrm{b}$ antigen after transport to the laboratory and storage at $-20^{\circ} \mathrm{C}$ for two months. Two specimens positive on culture for Haemophilus inftuenzae were posted to the laboratory and on receipt were negative for antigen by CIE and COA, and were not included in the results. Specimens should be tested for antigen as soon as possible after receipt in the laboratory. One cross-reaction was observed with the prototype meningococcus $\mathrm{COA}$ reagent, but instructions supplied with the meningitis kit directed that CSF specimens should be tested with all four reagents, and the false-positive reaction was easily detected.

The meningococcus COA reagent appears to be less sensitive than the pneumococcus or Haemophilus infuenzae type b reagents (Table 4), a phenomenon previously reported with "homemade" reagents. ${ }^{68}$ Although one study ${ }^{8}$ found the $\mathrm{COA}$ technique equally sensitive for the detection of meningococcal antigen of groups $\mathrm{A}, \mathrm{B}$ and $\mathrm{C}$, it is known that the commercially available group B meningococcal antisera are less sensitive than those of other groups. ${ }^{11} 1214$ For various reasons involved in the collection of specimens from several laboratories, and storage over a period of 18 months, the groups on only four of the eleven meningococcal CSFs tested are known; two group C specimens were positive on CIE and COA, two group B specimens were negative on CIE and COA. The meningococcus COA reagent is prepared with antisera to groups A, B, C, Y and W135, and further studies on CSFs containing the antigens of these groups are indicated.

A coagglutination kit of ready-for-use reagents will provide all laboratories with the facility for bacterial antigen detection in CSF specimens. COA has been shown to be as sensitive as CIE and is a useful test in support of established methods of direct microscopy and culture for the diagnosis of bacterial meningitis.
I should like to thank the microbiologists of West Yorkshire who submitted specimens of CSF, including $\mathrm{Dr} \mathrm{D}$ Telford of the Leeds Public Health Laboratory, and particularly thank the staffs of the laboratories mentioned in the text and their consultants: Dr WM Edgar, Dr AR Feeney and Dr M Mohanraj.

Pharmacia (Great Britain) Ltd, provided the reagents used in the study.

\section{References}

${ }^{1}$ Kelsey MC, Lipscomb AP, Mowles JM. Limulus amoebocyte lysate endotoxin test: an aid to the diagnosis in the septic neonate. J Infect 1982;4:69-72.

${ }^{2}$ Curtis GDW, Slack Mary PE, Tompkins DS. Cerebrospinal fluid lactate and the diagnosis of meningitis. $J$ Infect 1981;3:159 65.

${ }^{3}$ Peltola Heikki O. C-reactive protein for rapid monitoring of infections of the central nervous system. Lancet 1982;i:980-3.

4 Coonrod JD, Rytel MW. Determination of aetiology of bacterial meningitis by counterimmunoelectrophoresis. Lancet 1972;i:1154-7.

${ }^{5}$ Greenwood BM, Whittle HC, Dominic-Rajkovic O. Counter current immunoelectrophoresis in the diagnosis of meningococcal infections. Lancet 1971;ii:519-21.

- Thirumoorthi MC, Dajani AS. Comparison of staphylococcal coagglutination, latex agglutination and counterimmunoelectrophoresis for bacterial antigen detection. J Clin Microbiol 1979;9:28-32.

' Fung JC, Wicher K. Minimum number of bacteria needed for antigen detection by counterimmunoelectrophoresis: in vivo and in vitro studies. J Clin Microbiol 1981;13:681-7.

${ }^{8}$ Olcen P. Serological methods for rapid diagnosis of Haemophilus infuenzae, Neisseria meningitidis and Streptococcus pneumoniae in cerebrospinal fluid: A comparison of co-agglutination, immuno-fluorescence and immunoelectroosmophoresis. Scand J Infect Dis 1978;10:283-9.

- Shackleford PG, Campbell J, Feigin RD. Counter current immunoelectrophoresis in the evaluation of childhood infections. J Pediatr 1974;85:478-81.

${ }^{10}$ Moody GJ. Methodology and applications of countercurrent immunoelectrophoresis in microbiology. Laboratory Practice 1976;25:575-80.

"Anhalt JP. Fluorescent antibody procedures and counterimmunoelectrophoresis. In: Washington JA, ed. Laboratory procedures in clinical microbiology. New York: Springer-Verlag, 1981:249-77.

12 Tobin BM, Jones DM. Immunoelectro-osmophoresis in the diagnosis of meningococcal infections. $J$ Clin Pathol 1972;25:583-5.

${ }^{13}$ Feldman WE. Effect of prior antibiotic therapy on concentrations of bacteria in CSF. Am J Dis Child 1978;132:672-4.

14 Jones DM. The rapid detection of bacterial antigens. In: Reeves DS, Geddes AM, eds. Recent advances in infection. I. Edinburgh: Churchill Livingstone, 1979:91-107.

Requests for reprints to: Dr DS Tompkins, Department of Microbiology. The University of Leeds, Leeds LS2 9JT, England. 